\title{
Consequences of Ethnic and Madhesh Movements of Nepal ${ }^{1}$
}

Sedunath Dhakal ${ }^{2}$

\begin{abstract}
This paper explores on the consequences of ethnic and regional conflicts in Nepal, and also clarifies about how the recognition of Madheshi people deferred after the Madhesh movement -2015 . Conflict has really created the misunderstanding and gap to split the deep and long time relationship among different ethnic and regional people living harmoniously in Nepal since long in its history. It has also changed the attitudes and perspectives of Nepali people to look at India and China, Nepal's two neighbours. Further it made Nepal as a state able to rethink about alternatives for lessening dependency and to step ahead for strengthening its sovereignty.
\end{abstract}

\section{Keywords:}

\section{Madhesh Andolan, ethnic conflict, Nepal, India, China}

Nepal has faced multiple political problems after the restoration of democracy in 1990. Thousands of people have been killed, and millions have been affected during the two decades after the Maoist's armed movement against the systems of the state began in 1996. The movement supported the ethnic and regional movements too. The recent ethnic conflicts and the Madhesh Andolan 2015 during and after the promulgation of Constitution of Federal Democratic Republic Nepal on 20 September 2015 have created socio-political problems in Nepal.

Regional and ethnic movements of Nepal have apparently raised the voice for the proportional representation. But, these movements rather seem to be the "protests for recognition" (Sijapati 45). The recognition has deferred further but it, as a by-product, has incurred other impacts like the changed perspectives of the people on 'Madhesh-Pahad relationship' and 'international relations' of Nepal with its neighbours.

1 This paper was presented on August 18, 2016 in the New Regionalism Workshop held in Kathmandu from August 17 to August 19

2 Lecturer at Koteshwor Multiple Campus

3 People from the plain southern region, down to Siwalic Hills from the East to West of Nepal

4 Second Madhesh Movement began from the end of August, 2015 which continued for months after the Constitution of Nepal was promulgated on 20 September, 2015. 
Since the advent of Shah Dynasty from Prithvi Narayan Shah ${ }^{5}$ the rulers of Nepal gave privilege only to the so-called upper caste hilly people and their Nepali language, which always became only one official language of the state. Inequality prevailed throughout the country; Bahun, Chhetry, people from Pahade ${ }^{6}$ community got every governmental and social opportunities. According to World Bank and DFID report 2006, those upper caste people had "higher health indicators, longer life expectancy, higher rates of school attendance and lower levels of poverty than other groups in Nepal" (Quoted in Hangen and Lawoti, 13). But after 1990, concept of nationalism had not only been limited to Hindu, unitary Nepali speakers especially from Hill regions, and thus, different identities movements began (Hangen and Lawoti 5). It was because of the extreme form of domination of the state in support of the privileged upper caste people, the grievances of the underprivileged groups occurred.

Ethnic based and regional parties were formed after the democratic exercises began in Nepal after 1990. Main agenda of some of the parties were the fulfillments of the demands of certain ethnic or regional community people."Among them were: Nepal Rastriya Jana Mukti Morcha (NRJMM), Nepal Sadbhawana Party (NSP), Nepal Rastriya Jana Mukti Party (NRJMP), and Nepal Janajati Mahasangh (NJM)" (Bhattachan 35). After 1990, identity became a serious issue in the socio-political discourse of Nepal. Ethnic people throughout the country and the people living in the Tarai region involved in such parties started raising the voice for equality, justice and rights.

Right from the next day after Maoist and seven parties announced the Interim Constitution?, people from Tarai communities, led by "Madheshi Jana Adhikar Forum (Madheshi People Right Forum) and other Tarai based political parties began Madhesh Andolan (Madhesh Movemet) against the constitution" (Kantha 156), which couldn't guarantee their rights. The movement turned into violent conflict in which "30 people were killed and some 800 wounded within 21 days" (Sijapati 145). It was stopped with 22 Points Agreement ${ }^{8}$ which facilitated them to participate in the Constitutional Assembly (CA)

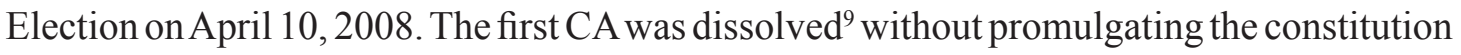
and Nepal had to again conduct the second CA Election on 19 November, 2013. When the Madheshi people realized that the CA wouldn't address their demands as they were included in the previous agreements in the new constitution, they began second Madhesh Movement. It was led by 'United Madheshi Front' (Samyoukta Madheshi Morcha) that combined almost

5 The King of Gorkha (1723-75) who became the king of united Nepal after he conquered many small states in 1769

6 People originally from Hilly region

7 Interim Constitution of Nepal promulgated on January 15, 2007

822 Point Agreement between the government and MJF held on 30 August, 2007 ( see the Appendix 3)

9 On May 27, 2012 
all Madhesh based parties except Bijya Kumar Gachhadar led Madheshi Jana Adhikar Forum -Loktantric (Madheshi People's Rights Forum -Democratic). "But, in response to the growing protests, the Madhesi People's Rights Forum - Democratic(MPRF-D), the only Tarai-based party supporting the 'fast track' constitutional process, leftthe 4-party alliance on September 8" (Human Rights Watch 8). The Madhesh became stronger for the protest after all Madhesh based parties were out of the process to finalize the constitution. At the time and after the promulgation of the Constitution of Federal Democratic Republic Nepal on 22 September 2015, the Madhesh movement again turned into violent conflict, in which "more than 50 people have been killed" (Thakur).

Both ethnic and regional conflicts of Nepal have created some sorts of misunderstanding and disharmony in Nepali society. There are two different types of attitudes and perspectives prevalent in the socio-political discourse about the consequences of the conflicts in Nepal. The ethnic (Janajati) and Madheshi people opine that the state which is often in the hands of Chhetri-Bahun and Pahade community people has created the anti-ethnic and anti-Madheshi discourse. But some of the ethnic and Madheshi people have not felt the ownership of the new constitution. They say it could not end the discrimination against Madheshi and other ethnic people as there are "many types of discrimination and exclusion suffered by Madheshis, Tharus and Janjatis" (Shah). Different ethnic groups were protesting against the state demanding the independent states like Tharuhat, Magarat, Limbuwan, Khambuhan,Tamsalin, Tamuwan etc. But in contrary to this, people from Chhetri-Bahun and Pahade community opine that the ethnic and Madhesh movements are against the sovereignty of the nation.

Nepal has been totally depended on the imports from and through India. The situation became worse after there was complete blockade in all the transit points at the climax of Madhesh Andolan. "The situation worsened some months and there came a humanitarian crisis"(Paudyal). According to the Pahade community people Madhesh movement was indirectly supported by the people from India which was against the sovereignty of the nation. But the Madheshi people don't agree such argument because the people in Madhesh have very close socio-economic and cultural connections to the people across the border which cannot be well-planned and organized support to the people in Madhesh. But they say its humanitarian support.

One of the major reasons of Madhesh Movement was grievance. All Madheshi people were united with the same demands: to guarantee the rights included in previous agreements: end of all forms of discrimination, participation of Madheshi people in the state mechanism, constituencies on the basis of population, inclusion of Madheshis in the army and police. "Madhesh identity has been used in order to turn historical grievances into political opportunities mobilize grassroots support and justify violence against the 
state "(Milklian 6). The mass mobilization in the movement was possible because of the grievance and collective identity.

Madheshi people participated in different movements not only for the representation in the state affairs, but also for the recognition that they have not yet felt. Madhesh Movement of 2015 turned into different quest quite contrary to the earlier movement of 2007 which ended with the 22 point agreements, and the amendment of Interim Constitution ${ }^{10}$. There was a loss of life and property, many innocent people and the security personals were killed, many got injured and displaced. The boarder crisis during months after the promulgation of constitution created a lot of problems in import and export of Nepal. But it was not the interest of Madheshi people. The newly promulgated "constitution created a new culture of activism in the Tarai where people were forced to become part of the uprising after their own security forces did not think twice before shooting more than 50 people" ( Thakur). There had been no option for the Madheshi people as Thakur opines; "unfortunately, the people resorted to violence against the police"(Thakur). It also weakened the MadheshPahad mutual relationship.

The movement has created a socio-political problem in Nepal. People started arguing in support and against the movement and the policy India took to look and perform in Nepal in such scenario. The people from Madhesh who were directly involved in the movement tried to get moral and other supports from the people and leaders of India because it was, they thought, the genuine movement for the rights, justice and equality for the marginalized and excluded people. Madheshi people believe that they had been segregated and excluded from the beginning of the Shah dynasty. They thought that the concept of communal harmony was the false consciousness created by Prithvi Narayan Shah in order to rule over the innocent people from different ethnic communities, and all the successive rulers from Shah Dynasty, Ranas and the governments after the restoration of democracy continue the same. "In order to consolidate his control over the newfound country, he put in place a ladder of communal hierarchy, militarist structure of governance, and patrimonial pattern of sharing the loot in acquired territories" (Lal). Lal further opines that the role of rulers to rule the Madheshi and other ethnic minority people with Pahade consciousness remained "intact even after nearly two-and-half centuries. There is a reason the so-called 'Khas-Arya' is the only group to find a definition in the new constitution: They are inheritors of the Gorkhali victory" (Lal).

The Madhesh conflict of Nepal has not settled properly, rather it helped to bring some conceptual changes in the Nepali people to look at India and China. There is an anti-Indian discourse created by some of the Pahade community people, and at the same time, there is an anti-Pahade discourse created by some Madheshi community which may

10 The Amendment of Nepal's Interim Constitution on February 8, 2008. 
ultimately result a split in harmonious Nepali society. According to Pankaj Chaudhari, an inhabitant from Janakpurdham, Dhanusa, "the Madheshi people have been tolerating for the centuries, now came the time to defeat the Hilly people and get the right" (Chaudhari) ${ }^{11}$ The people from Pahade origin started thinking about alternative way out from the dependency of Nepal only with India which is not immediately possible. "The Madhesh movement was designed with the motives of making Nepal always dependent upon India and the government should not compromise with the demands of Madheshi people"12 Murari Prasad Dhakal, a local household from Biratnagar, Morang reasoned. Such arguments and counter arguments and people's thinking alternative way out from the trade and other relation with India really affects the Nepali society because India-Nepal's relationship is not only of the trade; it is socio-cultural too. But, because the problem remained the same for months, different opinions for and anti Madhesh movements were heard throughout Nepal. The state has started to explore the possibility of the trade relation (import and export) with other countries by going beyond India. "There is no option for Nepal but to reduce its dependency on India, and to look to diversify its trade and commerce with other countries in the region-and beyond" (Bista). Nepal should think seriously about "its own productions using available raw materials instead of worrying about how to import from other countries" (Karna) $)^{13}$. Many others opine that Nepal has to develop good and long-term relationship with China in a different height. For that "Nepal needs to make several policy changes. The most important one is creating a symmetric market framework-infrastructure, rules and policies - for both the countries" (Acharya). Nepal- China trade agreement ${ }^{14}$ during the state visits of the former prime minister of Nepal, K. P. Oli in China is taken as a remarkable turn of Nepal to import the fuels and other materials from China. No doubt, the Madhesh conflict and boarder crisis between Nepal and India that the internal conflict of Nepal itself has created a difficult problem in Nepali society, yet it has become a right opportunity to think and find out a long-lasting solution for the Nepali society and its people.

\section{Conclusion}

Ethnic and regional conflict has become a great challenge in Nepal nowadays. There is also the problem in implementing the constitution because of the disownment of the new constitution of Nepal by many Madheshi and ethnic community people. It should address the demands of concerned people without "exploitation and misinterpretation" (Karki). The attitudes of Nepali people among each other, and to look at India and China has been changed which should be properly managed. The proper way to address the demands of

11 Interview with Pankaj Chaudhari on 22 July 2016

12 Interview with Murari Prasad Dhakal on 24 July 2016.

13 Interview with Manoj Kumar Karna on 28 July 2016

14 Bilateral Trade Agreement between China and Nepal held on March 21, 2016 
people is by amending the constitution which should address the demands of the Madheshi and ethnic people too. Every citizens of this country has been directly or indirectly affected by the prolonged conflicts. The wounds of such prolonged conflicts should properly be healed after transforming the nation into a peaceful and permanent democratic system. The constitution should unite all Nepali people in and outside the country properly. All should feel its ownership. Yet, it's not an absolute document, so can be amended and changed with the mandate of the citizens. The state should try to address the demands of rights, justice, representation, and ultimately the recognition of the people of all ethnic groups and the geographical regions. There came some misunderstanding between Nepal - India relationship because of the Madhesh Movement and the boarder crisis of 2015, which should be settled diplomatically. The most important thing Nepal has to do is the proper management of protracted ethnic and regional conflicts; addressing the genuine demands of all ethnic minorities, and excluded people to create the common feeling of national unity, cooperation and social harmony to lead the country towards political stability and economic prosperity.

\section{Works Cited}

Acharya, C. "Neighbouring with the north". The Kathmandu Post. 25 March 2016. Web. 12 July 2016. http:kathmandupost.ekantipur.com/news/2016-0325/neighbouring-withthe- north.html

Bhattachan, Krishna B. Ethnopolitics and ethnodevelopment: an emerging paradigm in Nepal - with a postscript. Ed. Hangen, Susan and Lawoti, Mahendra. Nationalism and Ethnic Conflict in Nepal. London: Routledge, 2013. 35 - 57. Print

Bista, Kritinidhi. "Suicidal India”. Republica. 20 Jan. 2016.Web. 25 June 2016

http://admin.myrepublica.com/opinion/story/35455/suicidal- india.html\#sthash.S4XIJJHg.dpuf

Hangen, Susan and Lawoti, Mahendra. Nationalism and ethnic conflict in Nepal. Ed. Hangen, Susan and Lawoti, Mahendra. Nationalism and Ethnic Conflict in Nepal. London: Routledge, 2013. 5 - 34. Print

Human Rights Watch. Like we are not Nepali: Protest and police crackdown in the Tarai region of Nepal, 2015. Web. 17 July 2016. http://www.hrw.org

Kantha, Promod K. . Maoist - Madhesi dynamics and Nepal's peace process. Ed. Lawoti, Mahendra and Pahari, Anup K. The Maoist Insurgency in Nepal. London: Routledge, 2010. 156-172. Print

Karki, Saugat Bikram. "Three Friends”. The Kathmandu Post. 20 March, 2016. Web. 10 July 2016. http://kathmandupost.ekantipur.com/news/2016-03-20/three-friends.html

Lal, C. K. “A dysfunctional state”. Republica. 11 Jan. 2016. Web. 11 July 2016 
http://admin.myrepublica.com/opinion/story/34733/a-dysfunctional-state. httm\#sthash.7cWD2WtL.dpuf.

Milklian, Jason. Nepal's Tarai: Constructing an Ethnic Conflict. Oslo: International Peace Research Institute, Oslo (PRIO), 2008. Web. 16 June 2016. http://www.prio.no

Paudyal, Mahabir. "India wants Nepal under perpetual siege”. Republica. 8 Dec. 2015. Web. 15 June 2016. http://nepalforeignaffairs.com/india-wants-nepal-under-its- $9 \mathrm{i}=8$ perpetualsiege/

Shah, Sukhdev. “The Pahade Bias". Republica. 28 Sept. 2015. Web. 19 June 2016. http:// admin.myrepublica.ccom/opinion/story/28921/the-pahade- bias.html\#sthash. wGmLorOB.dupf

Sijapati, Bandita. In persuit of recognition: regionalism, Madhesi identity and Madhes Andolan. Ed. Hangen, Susan and Lawoti, Mahendra. Nationalism and Ethnic Conflict in Nepal. London: Routledge, 2013. 145 - 172. Print

Thakur, Atul K."Comedy of political errors". The Kathmandu Post. 31 Jan., 2016. Web. 11 July 2016 http://kathmandupost.ekantipur.com/news/2016-01- 31/comedyof-political-errors.hotml 